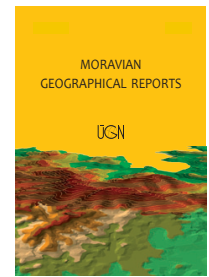

MORAVIAN GEOGRAPHICAL REPORTS

\title{
Retail format competition: The case of grocery discount stores and why they haven't conquered the Chinese market (yet)
}

\author{
Sina HARDAKER ${ }^{\text {* }}$
}

\begin{abstract}
The international expansion of the German discounters Aldi and Lidl in recent years has been a large success in grocery retailing. In China, the world's largest grocery retail market, however, grocery discounters have not (yet) established a physical store presence. In 2017 Aldi Süd and Lidl for the first time entered a new market without the help of a physical store, implementing an online shop in China. As to the format's future, significant disagreement amongst retail experts exists. This paper, which is based on qualitative interviews with high-ranking senior executives of international retailers, argues for three major reasons as to why the discount format has not hitherto gained a foothold in the Chinese market. Firstly, due to the characteristics and challenges of China's market, such as high fragmentation as well as the need for strong localisation, a high standardisation of the format is not possible. Secondly, the extremely low-margin operation of discounters faces a price level in China that is already very low, limiting one of the discounter's major competitive advantages. Thirdly, the discount format is facing a lack of consumer acceptance, toughening the establishment of private brands, which represents one of the major characteristics of the discount format.
\end{abstract}

Keywords: discount, grocery retail, format competition, internationalisation, Aldi, China

Article history: Received 25 January 2018; Accepted 25 July 2018; Published 30 September 2018

\section{Introduction}

While the internationalisation of the retail industry is not a new phenomenon, the breadth and speed of its expansion into new markets in the last decade is unprecedented (Dawson and Mukoyama, 2014, p. 227). Even so, the internationalisation process of retailers is not always successful. On the contrary, grocery retailers frequently report major difficulties in realising the potential offered by entering new markets. Very often, the format's market share remains relatively small compared to the host countries. In some cases, companies concede their ultimate failure, having to leave the market entirely. This phenomenon has created a large body of academic literature discussing international retail divestments (Burt et al., 2004; Palmer, 2004; Alexander et al., 2005; Coe et al., 2017).

Misjudgment of markets can lead to unwanted consequences, demonstrated by several prominent examples: Walmart in Germany (Christopherson, 2007) and SouthKorea (Halpete et al., 2008); Ahold in Latin America (Wrigley and Currah, 2003); Ahold (Palmer and Quinn, 2007) and Park and Shop in China (Goldman, 2000); Marks \& Spencer in Canada (Alexander, 1997, p. 286), in the USA (Burt et al., 2002) and Germany (Alexander and Quinn, 2002, pp. 119-120); Walmart and Carrefour in Korea (YoungSang, 2011, p. 13); or Tesco's 'Fresh \& Easy' in the USA (Euromonitor, 2013). Nevertheless, the internationalisation of retailers is continuing to increase, while especially the discounters' internationalisation strategies prove to be outstandingly successful. Apart from one example, namely Aldi Süd withdrawing from the Greek market in 2010 (Handelsblatt, 2010), the internationalisation process of discounters seems inexorable, with Aldi and Lidl stirring up markets in the UK, Australia and the USA, taking away big shares of long-established domestic players, such as Tesco, Woolworths and Coles.

Forecasts show that by 2020, Aldi will have even overtaken Carrefour in the European Ranking to take second place behind undisputed market leader Schwarz Group (Lidl, Kaufland) (Lebensmittelzeitung, 2017). The discounters gain share through their low-price structure and extensive range of private label products, forcing supermarkets and other industry players to reduce the cost of everyday items to compete. In 2003, Colla pointed out that the winners in the race to international expansion are the leaders of German hard discount retailers. One of the German companies that ventured relatively early abroad is

\footnotetext{
a Department of Economic Geography, Julius-Maximilians-University Würzburg, Germany (*corresponding author: S. Hardaker, e-mail: sina.hardaker@uni-wuerzburg.de)
} 
the food discounter Aldi. Aldi Süd has had its own branches in the United States since 1976, making it one of Germany's pioneers in the American market. As Acker (2010) reveals, in her study of Aldi's expansion into the United States, the format has been transferred (almost) unchanged and it clearly differentiates itself from the local competition.

Traill (2006, p. 163) investigated the rapid global rise of supermarkets and suggests that significant growth occurs in countries opening-up their markets and increasing their gross domestic product - both present factors within the Chinese market. Despite the discount model's global growth success story, however, the Chinese market, the largest grocery retail market in the world, has no typical grocery discount store in operation.

China's retail sector has experienced tremendous changes in the past few decades. Operating as a planned economy with most of the industries, including retailing, monopolised by state government until the $1980 \mathrm{~s}$, the Chinese Retail Revolution started to evolve in the early 1990s. Hardaker (2017), however, suggests that a consecutive process of format development is only apparent to a very limited degree within the Chinese market, as it has witnessed the entrance of modern store formats, rather than experienced a domestic development from within. Several formats have been introduced within a short period of time, enabling a simultaneous rather than consecutive development. Foreign retailers have brought with them new formats, predominantly the hypermarket format in the start-up phase, thereby initiating a dramatic alteration of the Chinese retailing landscape. While infrastructural problems were paramount in the $1990 \mathrm{~s}$, fierce competition and rising rental as well as labour costs, present the main challenges for the Chinese retailing sector at present.

This paper seeks to discover the specific reasons as to why no discount operator has yet entered the Chinese market with physical stores. Section 2 presents the theoretical background: the competition between formats is discussed in more detail, before the method is revealed in the following section. The paper is based on a wide range of expert interviews, among them leading international and Chinese grocery retailers, as well as several on-site observations of a wide range of existing retailers across China. Subsequently, the main results are discussed, which include several essential factors that account for the absence of the typical grocery discount format in China. The findings extend prior research by providing more comprehensive qualitative evidence regarding the challenges faced by international grocery discount retailers and the influences upon them. Finally, the article concludes by outlining a brief research agenda for work on format development and grocery discount stores in China.

\section{Theoretical background}

\subsection{Competition of retailing formats}

Understanding the nature of competition among grocery retailers is an important and active area of inquiry for both researchers and practitioners in retailing and has been a frequently- visited theme of research (Graff, 2006; Jing, 2013, p. 147). It is argued that "[c]ompetition in the retailing industry has reached dramatic dimensions" (Popkowski et al., 2000, p. 323), while Galvin et al. (2010) claim that China has become "the world's most important competitive battlefield." Two main types of competition can be distinguished: firstly, 'between-format competition', such as for instance between discount stores and hypermarkets, or superstores and traditional wet markets; and secondly, 'within-format competition', between retailers of the same format who are competing for customers and market share respectively (Fox and Sethuraman, 2006, p. 194).

While it is expected that geographical and economic segmentation in modern retail chain adoption rates is relevant, further factors regarding consumers are often overlooked. Consumption habits, mode of food preparation and shopping habits are essential elements when deciding to shop within a certain retailing format. Goldman et al. (2002, p. 82) suitably describe the adoption of modern retail formats as taking place more rapidly by wealthier consumers because of access to better transport facilities and the time saving benefits of the one-stop shopping experience. The difficulties arising from attempts to simply categorise customers according to socio-demographic background are demonstrated by proven examples such as Aldi in Germany. Observations confirm the ambiguity of the customer base, often referred to as hybrid buying and justifying the expression of a 'Porsche-driving Aldi-buyer'. While a plethora of research exists that attempts to identify the motivations and socio-demographic characteristics of the different store format costumers, Gonzáles-Benito et al. (2005, p. 69) criticise the absence of research concerning competition between different retail store formats. They distinguish competition between different types of store formats and rivalry on an intra-format level, consequently the opposition amongst stores of the same format.

The literature on store formats can be traced back to discussions on 'cross shopping', which was primarily explored in the trade literature in the late 1970s (Cort and Dominguez, 1977). Focusing on special aspects of the retail mix (e.g. price, service) means that "retailers can compete on highly diverse dimensions" (Popkowski et al., 2000, p. 323). The academic literature has emphasised several highly influential factors determining grocery shoppers' behaviours and the consumer choice for a certain store format:

1. Price: prices of items within and across categories, which may vary from week to week with respect to promotions;

2. Variety: breadth or number of categories typically carried by the format;

3. Assortment: depth or number of items within a category;

4. Service: range of consumable and perishable benefits; and

5. Store location: Where the retail store is located and how this affects the costs of shopping to consumers.

Amongst the available formats, the literature and the trade press have emphasised 'Every Day Low Pricing' and 'High-Low Promotional Price' or 'Promotional Pricing' as two clear and opposing positioning choices. According to Jinglun (2003, p. 167), "[M] any international companies have employed an aggressive pricing strategy, and this has proved highly successful." Fox and Sethuraman (2006, p. 207) presage at the end of their investigation into retail competition, that global retailers such as Walmart and Carrefour achieve international success mainly due to their diversity of store formats. Due to the high saturation of many markets, several leading grocery retailers diversify in varying formats. The large majority of the leading food retailers worldwide practice a format portfolio, with each format targeting a certain consumer group and sales situation. Arguing that competition between formats is fundamentally different from competition within formats, 
Fox et al. (2002, p. 29) ask for further studies that include multiple geographic areas and larger panels. The research carried out in this paper exclusively focuses on 'betweenformat competition' from a retail expert point of view. Further, it is organised around the question of whether the discount format is suitable for the Chinese market and why it has not yet been established in one of the world's largest grocery retail markets.

\subsection{The discount format - characteristics and main competitive advantages}

When the Albrecht brothers took over the family business in 1945, they laid the foundation for the discount principle. Already by 1955, the network had increased to 100 branches in the Western part of Germany. One major change occurred when the two brothers introduced self-servicing: for the first time, customers were able to take food from the shelves themselves, revolutionising the way to shop. After the division of the company and the foundation of the two resulting Aldi Süd and Aldi Nord groups in the 1960s, Aldi (for Albrecht Discount) opened its first discount branch, as known today. In a rationally established salesroom, a small number of groceries was offered directly from boxes on pallets. Subsequently, a distinction between discount and full-range suppliers was firstly undertaken. Early in the 1960s, the grocery discount store Norma entered the market, follow by Plus, Lidl and Penny in 1972 and 1973. The format has since successfully been established in the German and European markets, as revealed by the increasing number of stores as well as the continuous growth of revenue share.

The German Institute for Retail Research defines discount stores as a format that offers a tight, tailored for rapid handling assortment for low prices. Since discounters need large item-specific purchasing volumes and high customer frequencies to execute this strategy, the discount business is almost exclusively operated by large companies with wide-ranging branch networks. Wortmann (2011, p. 103), who pointed out that in the English-speaking world, companies such as Walmart or Asda are called discounters, emphasises the importance and characteristics of the German discounters: namely the limited range and following a very aggressive 'everyday-low-price' strategy (Zentes et al., 2011, p. 34; Sonneck and Ott, 2006, p. 182). The 'nofrills-concept', offers products of low-price store brands, sold out of boxes with a high turnover speed (Zentes et al., 2011, p. 34; Ahlert et al., 2006, p. 290; Wortmann, 2004, p. 426). Furthermore, discounters can be sub-divided into soft and hard versions (Colla, 2003, p. 57): generally, relatively small in terms of store size, typically between $300-900 \mathrm{~m}^{2}$, hard discount stores, also known as limited-line or limitedassortment discounters, stock less than 1,000 product lines, largely packaged groceries, simply presented in practical furnishing. Merchandise may be displayed with the original manufacturer's packaging to reduce the cost of removing it. Importantly, goods are mainly 'own brands' or budget brands. Soft discounters, however, also known as extendedrange discounters, are slightly larger but with the same frugal characteristics.

The crucial difference lies in the wider range of products, typically stocking $1,500-4,000$ product lines. Soft discounters commonly carry own-label and budget brands, as well as leading brands at discounted prices (Hawkes, 2008, p. 660; Ahlert et al., 2006, p. 291; Colla, 2003, p. 57). Currently, hard discounters, such as Aldi, seem to be in transition: with rising numbers of branded products as well as extensive store conversions and modernisation processes underway, the branches gradually change the familiar face of the discounter landscape. The boundaries between discounters and full-line supermarkets like German Rewe or British Tesco become increasingly blurred (Hardaker, 2016, p. 12). Looking more closely at the key attributes of grocery discount stores, it becomes clear that they simultaneously represent its competitive advantages:

1. Low cost operations and merchandising: discount stores have 'everyday low cost' operations, with low cost store fit-outs and multi-skilled staff who reduce store operating costs. Merchandising is basic (for example, pallets are placed directly on the shop floor) while display shelving is limited;

2. Limited product range: discount retailers exercise strict range discipline to limit the number of products available in their stores;

3. Focus on price: the provision of low-priced goods is at the core of the discounter model. Prices are prominently featured in-store, typically in a high-profile position above the product itself, with the focus as much on price as it is on product in some cases;

4. Small store formats: core discount stores are relatively uniform in size and layout, which helps keep operating costs low. Typically, stores range in size from $800 \mathrm{~m}^{2}$ $\left(8,600 \mathrm{ft}^{2}\right)$ to $1,500 \mathrm{~m}^{2}\left(16,000 \mathrm{ft}^{2}\right)$; and

5. Limited role for branded products: discounters traditionally place emphasis on private label products, and often 'exclusive' labels that do not carry the store name.

\section{Method}

As a lack of understanding of the grocery discount format prospects in the Chinese market exists, this paper intends to answer the following questions:

- Why do discount stores, as occurring in Europe, not exist in China to date?

- Does the grocery discount format have a future in China?

- What are the main characteristics and challenges of China's market for the discount format?

Expert interviews are the focus of this research. The study is based on twelve qualitative interviews with highranking senior executives of international retailers, mostly Chief Executive Officers (CEOs) or the head of expansion, but also with retail specialists and consultants, as well as professors, to receive a more balanced observation of the industry (see Tab. 1). All interviews were conducted between January and March 2015. Among the interview partners of this study were eight grocery retailers listed in the top 20 grocery chains in China, as well as international grocery retailers not (yet) operating in China. All interviews conducted lasted 45 to 110 minutes and were partly recorded and all transcribed and analysed. A limitation of the nonreplicable one-off interviews is that respondents might be subjective in their assessments of their own company's skills and problems. Furthermore, some interviewees had often worked for several grocery retailers in the market and were therefore able to refer to more than one company during the interviews.

The results of this research contribute to work by researchers, current and future retailers and marketers, in considering the role of the discount store format and its development, acceptance and future in the Chinese market. 


\begin{tabular}{ll}
\hline Type of interviewee / organisation & Name / Function \\
\hline China Chain Store \& Franchise Association (CCFA) & Anonymous / Retail Analyst \\
Chinese Retailer & Anonymous / Head of Merchandising \\
Major Chinese Retailer & Anonymous / Director of Strategy Planning \\
Major Hong Kong Retailer & Anonymous / Commercial Director \\
Major International Retailer I & Anonymous / Vice President \\
Major International Retailer II & Anonymous / Chief Executive Officer China \\
Major International Retailer III & Anonymous / Chief Executive Officer South China \\
Major International Retailer IV & Anonymous / National Expansion Director \\
Professor for Retailing & Mrs. Zhu Yi / Professor of Retailing \\
Retail Analyst I & Mr. Stocker / Retail Expert and Consultant \\
Retail Analyst II & Mr. Qui / Retail Analyst and Consultant \\
Retail Consultant & Mr. Kampf / Retail Expert and Freelance Consultant \\
\hline
\end{tabular}

Tab. 1: The list of interview partners

\section{Results and discussion}

Common agreement exists that the discount format, as present in Europe and represented by companies such as Lidl (Schwarzkopf Group) or Aldi, does not have a physical store presence in China. Yet, since March 2017, Chinese customers have been able to purchase products from Aldi Süd and Lidl via the Tmall Global e-commerce platform. The discounters offer selected products such as wines, snacks and breakfast products. The online marketplace is operated by the Chinese Alibaba Group. One year after Aldi Süd's digital market entry, the German retailer envisages the opening of a stationary shop network, including 50 physical stores and a central warehouse within the next three years. The following sections discuss the main factors contributing to the circumstance that a physical store presence has not yet been established, intending to evaluate the format's future in the People's Republic of China (PRC), on which experts disagree.

\subsection{The need for localisation and the myth of one Chinese market}

As market penetration requires long-term efforts, an early entry to obtaining a strong position in the market is necessary. For example, the German discounters highly standardise their domestic concept in foreign markets, following a global internationalisation strategy. As Colla (2003, p. 58) argues, mainly the discounter (such as Aldi, Lidl or Netto) reveals strong international presence, but employing a mono-format and a global concept, which is usually modified and adjusted only to a very small degree. One interviewee argues that "Aldi usually educates its consumers, which is very unlikely to work in the Chinese market" (Interview III, 2015). Acker's (2010) research on Aldi's US-expansion reveals that the format has been transferred (almost) unchanged. American consumers are not used to pack their purchase themselves and initially could not use credit cards, consequently adapting to Aldi's discount concept. Most of the interviewees agree that this would not work in the Chinese market. Whatever opinion, the difficulty lies, inter alia, in the extremely high territorial embeddedness of grocery retailers' activities (Coe and Lee, 2006, p. 61).

The internationalisation in food retail proves to be especially difficult, as the customer must be directly addressed with an overall supply, consisting of provision of goods and services on site (Huang and Sternquist, 2007, p. 614). To a certain extent the food retailer must become a substantial part of the community itself, in which it wants to do business. As pointed out earlier, China's retail landscape is characterised by tremendous regional variations with respect to economic, cultural, demographic and constitutional factors (Hardaker, 2017). The National Expansion Director of a large international retailer counters that the main characteristic of the Chinese market lies in "the fact that there is no Chinese market" (Interview II, 2015). The freelance consultant and former Head of Business Development at Metro China supports this argument and claims the treatment from the company's perspective on a city-level, meaning that Metro has " 80 stores in 53 cities, so we treat it as 53 markets" (Interview V, 2015). This coincides with reports by Tacconelli and Wrigley (2009), Frank et al. (2014) and Siebers (2017), who point out the highly heterogeneous Chinese retail environment, including differing consumer preferences, as well as vast geographical, cultural and economic differences. The grocery retailing industry is still largely a local, city-based business due to the differences in consumers' tastes and behaviours. Exploring Chinese consumers' shopping experiences and preferences, Davis (2013), Frank et al. (2014) and Maruyama and Wu (2014) reveal that preference structures differ even more strongly along ethnic rather than geographical lines, most likely because ethnic differences involve larger cultural variance.

The different markets vary strongly with respect to tastes, spending power and consumer cultures. Respectively, China lacks a national market, which influences their spatial expansion and forces them to localise (Zhang and Wei, 2017). According to Siebers (2017, p. 23) these circumstances also lead to retail TNCs applying hybrid practices and adjusting the degree of their adaptation and alteration over time, showing both heterogeneous and homogeneous characteristics. Chuang et al. (2011) explore the structural paradox faced by retail multinational firms in China as they balance the competing demands of standardisation and localisation. With respect to the partial success of Walmart and Carrefour in China, Chuang et al. (2011, p. 460) highlight the importance of standardised business practices, explaining that the unique difficulties of the Chinese market are due to institutional settings that have generated a complex business environment. In their research on foreign hypermarket retailers in China, Zhang and 
Wei (2015) analyse how transnational corporations resolve the structural paradox between enforcing standardisation and conducting localisation. They argue that foreign hypermarket retailers are constantly adjusting to better embed in the Chinese market and to more effectively resolve the structural paradox.

Implementing a wide-ranging branch network, which is necessary to purchase huge volumes and to achieve high customer frequencies to transpose the discount strategy, seems very difficult. Consequently, it is argued that the need for localisation provides one reason as to why discount stores are not successfully represented in the highly heterogeneous Chinese market.

\subsection{Grocery discount stores: Everyone must be discount}

The importance of sales and purchasing volumes in discount retailing has been underlined by analysts of the format (Colla, 2003). The major difference in prices compared to supermarkets and hypermarkets for products of comparable quality, is the main competitive advantage and the principal criterion of choice of this formula. When interviewed, the CEO of 7Eleven in South China sees potential opportunities in the formats main competitive factor, price:

"[...] the current players [...] are still very much priceorientated, and that doesn't give much space to discounters right now. But again, you don't know what the reality will be in a few years from now. [...] the hypers will probably lose market share, as they are usually higher margin retailers, they might have to get money back from their food products, which will question their ability to stick to low-price-positioning? There is a risk that this will give market share to discounters. Again, it might depend on whether they stick to the aggressive price-strategy or not, I guess" (Interview IX, 2015).

The commercial director from ParkNShop China provides a more pragmatic answer:

"Discount stores? I would say yes. There is a market for everything in China. [...] But if they come, it should be soon, and they should operate in budget areas" (Interview XI, 2015).

This coincides with Zhen (2007, p. 230), who forecasts noticeable future growth of large retail players expected to establish discount chains. Yet, some interviewees argue that the current challenge facing discount stores in the Chinese market is the extreme low price of products already in supermarkets which offer a similar range of products. As one interviewee claims:

"Which consumers are not price sensitive? So far, only advanced and mature markets have been entered by the discount format, with usually an oligopoly hierarchy being evident and prices and revealing a stable and higher level" (Interview X, 2015).

The interviewed retail expert from China Chain Store and Franchise Association clearly reasons, "everyone is a discounter somehow" and that it is "not the right thing for the Chinese market" (Interview IV, 2015).

"Maybe in China 'discount' has a different meaning. Everyone has to offer discount, as it all depends on the offer" (Interview II, 2015).

The Fung Business Intelligence Centre (2013, p. 34) similarly attests to the increasing popularity of discount formats among consumers and retailers, with store numbers estimated at around 400. This figure, however, refers mainly to discount outlets. In 2013, Shanghai Bailian Group opened Wuxi Mall, its third discount outlet, proving that Chinese consumers are demanding formats that allow cost savings. Discount stores however, are not yet a significant channel, having only a limited presence in large cities, not following a rigorous discount concept as described in the case of German discounter Aldi, Lidl and others. Nevertheless, perhaps due to this lower-price focus, consumers are said to have the perception that products are of an average or lower quality (Song, 2011, p. 17), an opinion shared by most interviewees. According to the Assistant Director at CCFA, however, foreign brands in China are not only more expensive, but more trusted, as they are almost automatically associated with better quality. Consequently, several interviewees mentioned the possibility of private foreign labels branded as quality products.

This paper argues that the already low-price level in China represents a huge challenge for the provision of lowpriced goods, which is at the core of the discounter model. If discounters do not succeed in branding their private labels as quality products, their main competitive advantage cannot be realised, consequently hindering the introduction of grocery discount stores.

\subsection{The Chinese consumer and private brands}

The limited convenience and uninspiring shopping experience provided by discount stores, coupled with high rental costs and a supply chain that is difficult to manage, might hinder the growth of the discount format (Interview II, 2015). This interviewed Chinese professor clearly states that there is "no need for discount stores", inter alia due to the low-price level at wet markets and the lack of advantages to go shopping in a discount store "which doesn't offer any uniqueness to its customer" (Interview XII, 2015). Despite a global increase in private label goods (Zhen, 2007, p. 14; Song, 2011, p. 18), in China the introduction of

\footnotetext{
"own brands need(s) so much effort to control: firstly, the production, then the distribution. We don't have food-only-brands, because we thought it is too risky. But we have our own laboratories, which are very expensive" (Interview II, 2015).
}

In 2009 Tacconelli and Wrigley argued that the development of private labels in China was still in its embryonic stages (Tacconelli and Wrigley, 2009, p. 67). The retail analyst from Planet Retail clearly states that still today "discount stores are not working in China, as private labels are not accepted" (Interview VII, 2015). He further claims, however, that "it's not about the format itself; it is still a very new format." Yet, he asserts that the lack of trust in no name brands is the main reason for the unworkability of discount stores. Nevertheless, he highlighted the opportunity for international players to convince Chinese consumers of the trustworthiness of private brands, thus transforming them as acceptable new brands (Interview VII, 2015). Two interviewees highlight the example of Costco, an American retailer that recently tested the water in the Chinese market by offering private labels on the Internet. Selling out within three days, several experts agree that the retailer's brand reputation and customers' awareness was the main reason for its success, as many Chinese tourists travelling to the USA knew the brand (Interview II, 2015; Interview VII, 2015). German Aldi Süd is following a similar approach, offering a small selection of its own brands in an online shop since 2017, primarily entering a foreign market without implementing 
physical stores. The difficulties with respect to their own brands are omnipresent, as one interviewed expert refers to Dia, a very soft discount format that has been introduced to the Chinese market "with high expectations, which could not be met at all", due to the inability to achieve competitive prices (Interview V, 2015). Furthermore, own brands make up approximately 50\% of products offered and these are constantly reduced. The ParkNShop China commercial director's opinion on the Chinese consumer's brand fondness is clear:

"So, if I think about Aldi and Lidl, they are successful because firstly they served the lower-class customers that really say I don't need a brand, I want a good price and an ok quality. But Chinese customers really want brands. They are so brand sensitive: therefore, in China we have many retailers that have difficulties to launch their own brands [...] So if it's not a brand, they don't consider it. They don't know it, so it's not good" (Interview XI, 2015).

In 2011, Qui and Zhao (2011, p. 22), similarly to Song (2011, p. 16), did not forecast thriving success for discount supermarkets in the short term, arguing that private labels have not yet gained consumer acceptance. This paper finds support for this rationale, arguing that without the extensive range of private label products discounters cannot gain share through a low-price structure.

\section{Conclusion}

The national retail environment is crucial to the development of international retail companies, as well as different store formats. As Alexander (1997, p. 74) acknowledges, some markets "may not be ready for certain retail formats." Dupuis and Prime (1996, p. 32) assert that "when a retail format is exported it has to face a new context which may affect its original competitive advantage [...]." Alexander (1997, p. 117) reveals the result of new formats in a new market firstly through the transfer from one market to the other, and secondly through differentiated formats as a response from existing retailers in the target market. $\mathrm{He}$ further points out (op. cit., 1997, p. 307) that retailers seek to retain retail formats which they are familiar with.

Initially, operating from a low status position, the retailer evolves from a traditional position to a mature, high status one. Zhen (2007, p. 16) acknowledges the fact that the evolution of retail formats is increasingly accelerated, hence, shortening the life cycle of retail formats. Gonzáles-Benito et al. (2005, p. 59) briefly describe the transformation of store formats as a consecutive process with the introduction of supermarkets as the initial step, followed then by the larger versions of hypermarkets and the adjacent development of the discount store. In view of the Chinese market, such a consecutive process is only apparent to a very limited degree. The Chinese market has witnessed the entrance of modern store formats, rather than experiencing a domestic development from within. Also, within a short period of time, several formats have been introduced, enabling a simultaneous rather than consecutive development (Hardaker, 2017).

Despite the attractiveness of the Chinese grocery retail market, the grocery discounter format - although highly successful within their internationalisation process - has not entered the Chinese market yet. Companies in general prefer to enter markets that rank high in attractiveness, low in market risk and where they can enjoy a competitive advantage. This paper looks more carefully at the reasons as to why this is not the case for grocery discounters in the Chinese market. Despite the often-cited and argued price sensitivity of Chinese customers, retail discounters are not (yet) popular. Technically, discount stores do not exist in China to date. The conducted expert interviews revealed high disagreements with respect to the format's future in China. Whereas some retailers foresee a possible niche for discount stores, the Chinese interviewees express common incomprehension of the format, stating that it is not suitable for the Chinese consumer.

Predictions as to the promising future of the format in China are difficult. Yet, this paper argues for three major reasons as to why the discount format has not hitherto gained a foothold in the Chinese market. Firstly, due to the characteristics and challenges of the Chinese market, such as high fragmentation, fierce competition, the need for strong localisation as well as infrastructural issues, a high standardisation of the format, as existent in Europe for instance, is not possible. This is an essential difficulty that all retailers, irrespective of the adopted format, must face. Nevertheless, the discounter represents an extremely lowmargin operation and strives for price leadership, which leads to the second argument. As remarked by several interviewed experts, the price level in China is already very low, and "everyone has to be a discounter somehow" (Interview II, 2015), confiscating one of the discounter's major competitive advantages. Thirdly, most experts agree that the discount format is facing a lack of consumer acceptance. The absent of trust combined with the desire to demonstrate wealth, make it difficult for retailers to establish their own brands, which represents one of the major characteristics of the discount format. Moreover, given the increasing role of convenience, the discount format seems not to fit into the Chinese retailing landscape. Regarding the criteria of choice of country for discount retailers (mainly hard discounters), Colla (2003, p. 64) argues that mature markets with a dominance of supermarkets and strong brands is usually chosen when internationalising, hence providing a possible explanation for absence within the Chinese market.

Future research should continue to explore Chinese customers' perceptions of private brands, as well as their possibly changing awareness of retailers such as Aldi Süd and Lidl, which in 2017 entered the Chinese e-commerce market. China is the first foreign country Aldi, whose initial online-offer only includes 100 own label food lines, has ever entered without establishing a physical store network, supporting this paper's argumentation. Moreover, future research may involve the evaluation of the discount online shops with respect to preparing the ground for a physical discount presence in China's cities. Thought about the future of discount stores in less developed parts of China should also be discussed. More research is urgently needed on all these aspects of retail format development in China. From a geographical perspective, it is important to position our understanding of national market conditions influencing format development alongside processes operating at other spatial scales. In terms of sourcing, for example, do retailers establish regional sourcing patterns serving multiple markets within China, and how does this vary across different kinds of commodities? Besides, to what extent do they influence format adaption? As outlined earlier, consumer habits and tastes heavily diverge across different sub-national regions, as well as between urban and rural contexts, possibly providing niche markets for grocery discount retailers. 


\section{References:}

ACKER, K. (2010): Die US-Expansion des deutschen Discounters Aldi - Eine Fallstudie zur Internationalisierung im Einzelhandel. Geographische Handelsforschung $16^{\text {th }}$ ed. Passau, L.I.S. Verlag.

AHLERT, D., BLUT, M., EVANSCHITZKY, H. (2006): Current Status and Future Evolution of Retail Formats. In: Krafft, M., Mansala, M. K. [eds.]: Retailing in the $21^{\text {st }}$ Century - Current and Future Trends (pp. 289-311). Heidelberg, Springer.

ALEXANDER, N. [ed.] (1997): International Retailing. London, Wiley Business and Economics.

ALEXANDER, N., QUINN, B. (2002): International Retail Divestment. International Journal of Retail and Distribution Management, 30(2): 122-123.

ALEXANDER, N., QUIN, B., CAIRNS, P. (2005): International Retail Divestment Activity. International Journal of Retail and Distribution Management, 33(1): 112-125.

BURT, S., MELLAHI, K., JACKSON, T. P., SPARKS, L. (2002): Retail Internationalisation and Retail Failure: Issues from the Case of Marks and Spencer. International Review of Retail, Distribution and Consumer Research, 12(2): 191-219.

BURT, S., DAWSON, J., SPARKS, L. (2004): The International Divestment Activities of European Grocery Retailers. European Management Journal, 5: 483-492.

CHRISTOPHERSON, S. (2007): Barriers to 'US style' Lean Retailing: The Case of Wal-Mart's Failure in Germany. Journal of Economic Geography, 7(4): 451-469.

CHUANG, M. L., DONEGAN, J. J., GANON, M. W., WEI, K. (2011): Walmart and Carrefour experiences in China: resolving the structural paradox. Cross Cultural Management: An International Journal, 18(4): 443-463.

COE, N., LEE, J. (2006): The Strategic Localization of Transnational Retailers - The Case of Samsung-Tesco in South Korea. Economic Geography, 82(1): 61-88.

COE, N., LEE, Y. S., WOOD, S. (2017): Conceptualising contemporary retail divestment: Tesco's departure from South Korea. Environment and Planning A: Economy and Space, 49(12): 2739-2761.

COLLA, E. (2003): International Expansion and Strategies of Discount Grocery Retailers: The Winning Models. International Journal of Retail and Distribution Management, 31(1): 55-66.

CORT, S., DOMINGUEZ, L. (1977): Cross-Shopping and Retail Growth. Journal of Marketing Research, 14(2): 187-192.

DAVIS, L. Y. (2013): Let Us Go Shopping: Exploring Northwest Chinese Consumers' Shopping Experiences. International Journal of Consumer Studies, 37(4): 353-359.

DAWSON, J., MUKOYAMA, M. (2014): Future Directions of Retailer Internationalization. In: Dawson J., Mukoyama M. [eds.]: Global Strategies in Retailing - Asian and European Experiences (pp. 227-238). New York, Routledge.

DUPUIS, M., PRIME, N. (1996): Business Distance and Global Retailing: A Model for Analysis of Key Success / Failure Factors. International Journal of Retail \& Distribution Management, 24(11): 30-38.
EUROMONITOR (2013): The Internationalization of Retailing - Success, Failure and the Importance of Adapting to the Market [online]. Available at: http:// web.euromonitor.com/Portals/71592/docs/FINAL_The_ Internationalisation_of_Retail_DigitalVersion.pdf

FOX, E. J., SETHURAMAN, R. (2006): Retail Competition. In: Krafft, M., Mantrala, M. K. [eds.]: Retailing in the $21^{\text {st }}$ century - Current and Future Trends (pp. 193208). Heidelberg, Springer Verlag.

FOX, E. J., MONTGOMERY, A. L., ALAN, L., LODISH, L. M. [eds.] (2002): Consumer Shopping and Spending Across Retail Formats. Pittsburgh, Carnegie Mellon University.

FRANK, B., ABULAITI, G., ENKAWA, T. (2014): Regional differences in consumer preference structures within China. Journal of Retailing and Consumer Services, 21(2): 203-210.

FUNG BUSINESS INTELLIGENCE CENTRE (2013): Retail Market in China [online]. Available at: http:// www.funggroup.com/eng/knowledge/research/china_dis_ issue114.pdf

GALATA, G., BUCKLIN, R. E., HANSSENS, D. M. [eds.] (1999): On the Stability of Store Format Choice. Los Angeles, University of California.

GALVIN, J., HEXTER, J., HIRT, M. (2010): Building a Second Home in China. McKinsey Quarterly, 1-16.

GOLDMAN, A. (2000): Supermarkets in China: The Case of Shanghai. The International Review of Retail, Distribution and Consumer Research, 10(1): 1-21.

GOLDMAN, A., RAMASWAMI, S., KRIEDER, R. (2002): Barriers to the Advancement of Modern Food Retail Formats: Theory and Measurement. Journal of Retailing, 78(4): 281-295.

GONZÁLES-BENITO, Ó., MUNOZ-GALLEGO, P., KOPALLE, P. K. (2005): Asymmetric Competition in Retail Store Formats: Evaluating Inter- and Intra-Format Spatial Effects. Journal of Retailing, 81(1): 59-73.

GRAFF, T. O. (2006): Unequal Competition among Chains of Supercenters - Kmart, Target, and Wal-Mart. The Professional Geographer, 58(1): 54-64.

HALPETE, J., IYER, K. V. S., PARK, S. C. (2008): Walmart in India: A Success or Failure? International Journal of Retail \& Distribution Management, 36(9): 701-713.

HANDELSBLATT (2010): Aldi verlässt Griechenland [online]. Available at: http://www.handelsblatt.com/ unternehmen/handel-dienstleister/rueckzugaldiverlaesst-griechenland/3492242.html

HARDAKER, S. (2017): The changing role of international grocery retailers in China, 1978-2016. History of Retailing and Consumption, 3(1): 53-69.

HARDAKER, S. (2016): Aldi, Lidl \& Co.: Geht die Ära der Discounter wirklich zu Ende? Geographische Handelsforschung, 39: 9-13.

HAWKES, C. (2008): Dietary Implications of Supermarket Development - A Global Perspective. Development Policy Review, 26(6): 657-692.

HUANG, Y., STERNQUIST, B. (2007): Retailers' Foreign Market Entry Decisions: An Institutional Perspective. International Business Review, 16(5): 613-629.

JING, L. (2013): Analysis of China's Large Supermarket Service Competition Strategy. Modern Management, 3: 147-151. 
JINGLUN, H. (2003): The Reform of the Distribution System in China - Opening the System to the Outside World. In: Dawson, J., Mukoyama, M., Choi, S. C., Larke, R. [eds.]: The Internationalisation of Retailing in Asia (pp. 155168). Los Angeles, Routledge Curzon.

LEBENSMITTELZEITUNG (2017): Retailer Ranking Aldi Will be Number Two in Europe by 2020 [online]. $18^{\text {th }}$ May 2017. Available at: http://www.lebensmittelzeitung. net/european-view/Retailer-Ranking-Aldi-Will-beNumber-Two-in-Europe-by-2020-129176

MARUYAMA, M., WU, L. (2014): Quantifying Barriers Impeding the diffusion of Supermarkets in China: The Role of Shopping Habits. Journal of Retailing and Consumer Services, 21(3): 383-393.

PALMER, M. (2004): International Retail Restructuring and Divestment: The Experience of Tesco. Journal of Marketing Management, 20(9/10): 1075-1105.

PALMER, M., QUINN, B. (2007): The Nature of International Retail Divestment: Insights from Ahold. International Marketing Review, 24(1): 26-45.

POPKOWSKI, P. T. L., SINHA, A., TIMMERMANS, H. J. P. (2000): Consumer Store Choice Dynamics: An Analysis of the Competitive Market Structure of Grocery Stores. Journal of Retailing, 76(3): 323-345.

QIU, Y., ZHAO, J. (2011): Choosing the Right Retail Format. China Business Review, Issue July-September: 22.

SIEBERS, L. Q. (2016): Hybridization practices as organizational responses to institutional demands: The development of Western retail TNCs in China. Journal of Economic Geography, 17(1): 1-29.

SONG, W. (2011): Contributing Factors in Emergence and Growth of Chinese Grocery Own Brands. International Journal of Business and Management, 6(2): 13-23.

SONNECK, P., OTT, C. S. (2006): Future Trends in MultiChannel Retailing. In: Krafft, M., Mantrala, M. K. [eds.]: Retailing in the $21^{\text {st }}$ Century - Current and Future Trends (pp. 175-192). Heidelberg, Springer.
TACCONELLI, W., WRIGLEY, N. (2009): Organizational Challenges and Strategic Responses of Retail TNCs in Post-WTO - Entry China. Economic Geography, 85(1): 49-73.

TRAILL, W. B. (2006): The Rapid Rise of Supermarkets? Development Policy Review, 24(2): 163-174.

WORTMANN, M. (2004): Aldi and the German Model Structural Change in German Grocery Retailing and the Success of Grocery Discounters. Competition and Change, 8(4): 425-441.

WORTMANN, M. (2011): Globalization of European Retailing. In: Hamilton, G. G., Petrovic, M., Senauer, B. [eds.]: Market Makers - How Retailers are Reshaping the Global Economy (pp. 117-153). Oxford, Oxford University Press.

WRIGLEY, N., CURRAH, A. (2003): The Stresses of Retail Internationalisation: Lessons from Royal Ahold's Experience in Latin America. International Review of Retail, Distribution \& Consumer Research, 13(3): 221-243.

YOUNG-SANG, C. (2011): The Knowledge Transfer of Tesco UK into Korea, in Terms of Retailer Brand Development and Handling Processes. Journal of Distribution Science, 9(2): 13-24.

ZENTES, J., MORSCHETT, D., SCHRAMM-KLEIN, H. [eds.] (2011): Strategic Retail Management - Text and International Cases. $2^{\text {nd }}$ ed. Wiesbaden, Gabler.

ZHANG, L., WEI, Y.D. (2015): Foreign hypermarket retailers in China: spatial penetration, local embeddedness, and structural paradox. Geographical Review, 105(4): 528-550.

ZHANG, L., WEI, Y. D. (2017): Spatial inequality and dynamics of foreign hypermarket retailers in China. Geographical Research, 55(4): 395-411.

ZHEN, Y. [ed.]. (2007): Globalization and the Chinese Retailing Revolution - Competing in the World's Largest Emerging Market. Oxford, Chandos Publishing.

\section{Please cite this article as:}

HARDAKER, S. (2017): Retail format competition: The case of grocery discount stores and why they haven't conquered the Chinese market (yet). Moravian Geographical Reports, 26(3): 220-227. Doi: 10.2478/mgr-2018-0018. 